प्र

ディジタル通信システムのサンプル值 $H^{\infty}$ 設計*

永原. 正章

\title{
Sampled-data $H^{\infty}$ Design for Digital Communication Systems*
}

\author{
Masaaki NAGAHARA $^{\dagger}$ and Yutaka YAMAmoto ${ }^{\dagger}$
}

\begin{abstract}
A design procedure for data compression and equalization for digital communication systems is developed based on the multirate sampled-data $H^{\infty}$ control theory. The procedure provides transmitting/receiving filters so as to minimize the error between the original signal and the received signal with a time delay, and to reduce the noise added to the channel. While the system is multirate and infinite-dimensional due to up- and downsampling and a delay, the design problem can be reduced to a finite-dimensional discrete-time problem using the lifting and the FSFH (fast-sample and fast-hold) approximation. Numerical examples are presented to illustrate the effectiveness of the proposed method.
\end{abstract}

\section{1. はじめに}

インターネットや携帯電話等の急速な発展により, ディ ジタル通信の重要性はますます大きくなっている，ディ ジタル通信にはつぎのような利点がある [7]:

・情報を圧縮して効率の良い通信がおこなえる。

・情報を暗号化して伝送できる。

- 雑音に強い.

ディジタル通信では, 音声や画像などアナログの情報源 は標本化されたのちに送信装置によって通信路に送られ る. 従来のディジタル通信では, 情報源のアナログ特性 に着目することなく，ディジタル通信システム全体を離 散時間システムととらえた設計がおこなわれている。す なわち, 情報源のアナログ信号がナイキスト周波数以下 に完全に帯域制限されていると仮定し，標本化の影響を 無視して議論が進められることが多い.しかし実際には 完全带域制限の仮定は成り立たたず，ナイキスト周波数 以上の成分が情報源には含まれるはずである。したがっ て,より精密なディジタル通信システムの設計をおこな うためにはもとのアナログ信号の特性をも考慮する必要

\footnotetext{
* 原稿受付 2002 年 2 月 13 日

†京都大学 大学院 情報学研究科 Graduate School of Informatics, Kyoto University; Yoshida-Honmachi, Sakyo-ku, Kyoto 606-8501, JAPAN

Key Words: digital communications, data compression, sampled-data control.
}

がある、

近年，このような問題にたいしてサンプル值制御理論 が応用され，アナログ特性を考慮したディジタル信号処 理が提案されている $[5,12,6]$. 特に参考文献 $[6]$ において は, インターポレータの設計問題がマルチレートサンプ ル值制御系設計問題として定式化された。本論文では， サンプル值制御理論を用いたこの手法をディジタル通信 システムの設計に応用し，アナログ特性を考慮した送受 信フィルタの設計手法を提案する。すなわち, 送信信号 と受信信号との誤差系の $L^{2}$ 誘導ノルムを最小化する送 受信フィルタをサンプル值 $H^{\infty}$ 最適制御理論を用いて導 出する。

また，ディジタル通信においてはしばしば信号を圧縮 して送信することがおこなわれる．圧縮の操作はダウン サンプラで表現されるため, 送受信フィルタの設計はマ ルチレート系にたいするサンプル值 $H^{\infty}$ 最適設計とな る.このようなマルチレートサンプル值 $H^{\infty}$ 制御の研究 は従来より行われており $[3,8]$, 本論文でもそれらの研究 と同様の手法，すなわち離散時間リフティング [4] 導 入する。 それによって, 送受信フィルタの設計問題は単 一レートシステムにたいするサンプル值 $H^{\infty}$ 最適化問題 と等価となる.

さらに，設計問題はむだ時間を含む無限次元サンプル 值系であるが, ファーストサンプル・ファーストホール ド $(\mathrm{FSFH})$ 近似手法 $[11]$ を用いて近似離散時間系の設 
計問題に帰着する。

最後に数值例により，アナログ特性を考慮しない離散 時間領域での設計と提案手法を比較し, 本手法の有効性 を示す.

\section{2. 設計問題}

ディジタル通信システムのブロック線図を Fig. 1 に示 す. 連続時間信号 $w_{c} \in L^{2}[0, \infty)$ にたいして連続時間ロー パスフィルタ $F_{c}(s)$ を作用させ，信号 $y_{c}$ を得る。この $F_{c}(s)$ は伝送すべきアナログ信号の先見情報であると考 えることができる。パルス振幅変調 $(\mathrm{PAM})$ やパルス符 号変調 $(\mathrm{PCM})[7]$ では, 周期 $h / M$ で動作する理想サン プラ $\mathcal{S}_{h / M}$ によって連続時間信号 $y_{c}$ が離散時間信号 $y_{d}$ に変換される。信号 $y_{d}$ は送信フィルタ $K_{T}(z)$ から通信 路 $C_{d}(z)$ に送信される.

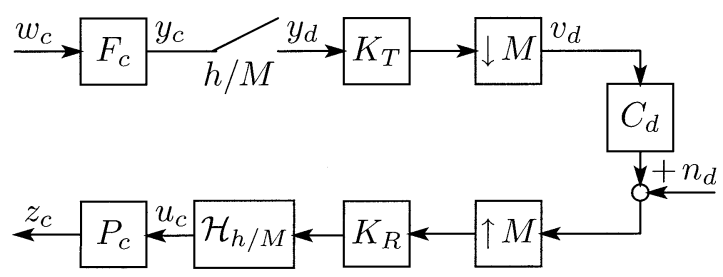

Fig. 1 Digital communication system

ここで，送信信号を圧縮し効率の良い通信をおこなう ために，送信フィルタの後にダウンサンプラ $M M$ が挿入 される。ダウンサンプラ $Ｍ$ は次式で定義される：

$$
\downarrow M: \psi_{d} \mapsto u_{d}: u_{d}[k]=\psi_{d}[M k]
$$

すなわち，ダウンサンプラは離散時間信号を $M-1$ 個間 引くことにより, サンプル周期を $M$ 倍させるシステム である，送信信号をダウンサンプルすることにより，信 号の情報量は $1 / M$ に減ることになる。

この送信信号が通信路に送られる。一般に通信路の特 性は複雑であり，とくに無線通信などではフェーディン グとよばれる非線形現象がみられるが，ここでは簡単の ため通信路を LTI モデル $C_{d}(z)$ であらわす。この通信路

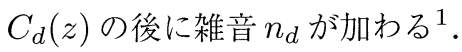

雑音を含んだ受信信号は $M$ 倍のアップサンプラ $\uparrow M$ により，サンプル周期 $h / M$ の信号に変換される.ここ でアップサンプラ $M$ は次式で定義される：

$$
\uparrow M: v_{d} \mapsto \phi_{d}: \phi_{d}[k]=\left\{\begin{array}{l}
v_{d}[l], k=M l, l=0,1, \ldots \\
0,
\end{array}\right.
$$

アップサンプルされた信号は受信フィルタ $K_{R}(z)$ を通 り, 周期 $h / M$ で動作する 0 次ホールドにより連続時間 信号に変換される。この連続時間信号がアナログフィル

\footnotetext{
${ }^{1} \mathrm{PCM}$ では $v_{d}$ にたいして量子化や符号化の操作が加わ るが，本論文ではそれらの影響を通信路に加わる雑音 $n_{d}$ とみなして設計をおこなう。
}

夕 $P_{c}(s)$ により平滑化されて出力信号 $z_{c}$ が得られる. ディジタル通信では，送受信フィルタ $K_{T}(z)$ および $K_{R}(z)$ を用いて, 通信路および付加雑音による受信信号 の劣化を抑制し，もとの信号 $y_{c}$ を忠実に再現する必要が ある。ここで送信フィルタ $K_{T}(z)$ は，通信路の特性 $C_{d}$ によって減衰する周波数帯域をあらかじめ増幅しておく 働きがあり，受信フィルタ $K_{R}(z)$ は伝送路で生じたひず みや雑音を除去する働きがある。これらのフィル夕によ る復元信号 $z_{c}$ ともとの信号 $y_{c}$ を比較するために Fig. 2 の誤差系を考える。ここで送受信フィルタによる復元過 程にはある程度の時間遅れが許されるため, 時間遅れ要 素 $e^{-L s}$ が用いられる。

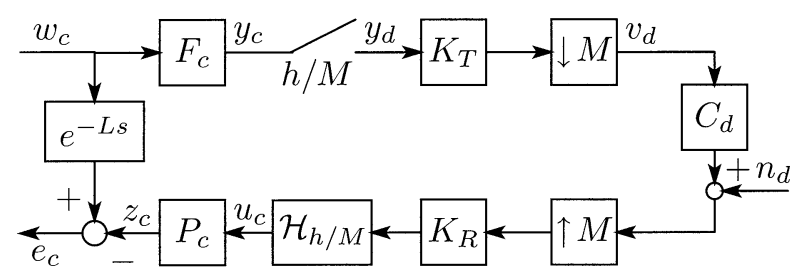

Fig. 2 Error system for design

このとき設計問題は以下のように定式化される:

【問題 1】安定かつ厳密にプロパな $F(s)$, 安定かつ プロパな $P(s)$, 安定な通信路 $C_{d}(z)$, 時間遅れ $L$ が与え られたとする。このとき

$$
J\left(K_{R}, K_{T}\right):=\sup _{w_{c} \in L^{2}, n_{d} \in l^{2}} \frac{\left\|e_{c}\right\|_{L^{2}}}{\sqrt{\left\|w_{c}\right\|_{L^{2}}^{2}+\left\|n_{d}\right\|_{l^{2}}^{2}}}
$$

を最小化する $K_{T}(z)$ と $K_{R}(z)$ を求めよ.

\section{3. 設計アルゴリズム}

\section{1 設計問題の分割}

問題 1 は送受信フィルタの設計問題であるが，これら を同時に求める問題は非凸な最適化問題であり，容易に 解くことはできない. したがって本論文では同時に二つ のフィルタを設計するのではなく, 問題を受信フィルタ の設計問題と送信フィルタの設計問題に分割する:

Step A Fig. 2 において送信フィルタ $K_{T}$ を固定し

$$
J_{1}\left(K_{R}\right):=\sup _{w_{c} \in L^{2}, n_{d} \in l^{2}} \frac{\left\|e_{c}\right\|_{L^{2}}}{\sqrt{\left\|w_{c}\right\|_{L^{2}}^{2}+\left\|n_{d}\right\|_{l^{2}}^{2}}}
$$

を最小化する受信フィルタ $K_{R}$ を求めよ.

Step B Fig. 2 において受信フィルタ $K_{R}$ を固定し

$$
J_{2}\left(K_{T}\right):=\sup _{w_{c} \in L^{2}} \frac{\left\|e_{c}\right\|_{L^{2}}}{\left\|w_{c}\right\|_{L^{2}}}
$$

を最小化する送信フィルタ $K_{T}$ を求めよ. 設計は $K_{T}$ の初期值を 1 とし, Step A と Step B を繰り 返す。

Step Bにおいて設計される $K_{T}$ は $n_{d}$ から $e_{c}$ までの 特性を変えることができないことに注意すると, Step A 
と Step B では最適化する評価関数は異なるが各ステッ プに扮いて (1) の目的関数 $J\left(K_{R}, K_{T}\right)$ は単調に減少す る.すなわち, 次の命題が成り立つ.

【命題 1】任意の整数 $n \geq 1$ にたいしてつぎの不等式 が成り立つ。

$$
J\left(K_{R}^{(n-1)}, K_{T}^{(n-1)}\right) \geq J\left(K_{R}^{(n)}, K_{T}^{(n)}\right) \geq J_{\mathrm{opt}}
$$

ただし， $K_{R}^{(n)}$ および $K_{T}^{(n)}$ は $n$ 回目の設計によって得ら れる送受信フィルタである。また

$$
J_{\mathrm{opt}}:=\min _{K_{R}, K_{T}} J\left(K_{R}, K_{T}\right)
$$

と扔く。

(証明) Fig. 2 に扔いて， $w_{c}$ および $n_{d}$ から $e_{c}$ までの システムをそれぞれ $T_{e w}\left(K_{R}, K_{T}\right), T_{e n}\left(K_{R}\right)$ とおく.ま ず $n$ 回目の $K_{R}$ の設計（Step A）に扔いて，

$$
K_{R}^{(n)}=\underset{K_{R}}{\arg \min _{1}} J_{1}\left(K_{R}\right)=\underset{K_{R}}{\arg \min _{R}} J\left(K_{R}, K_{T}^{(n-1)}\right)
$$

であるから，

$$
J\left(K_{R}^{(n-1)}, K_{T}^{(n-1)}\right) \geq J\left(K_{R}^{(n)}, K_{T}^{(n-1)}\right)
$$

が成り立つ.つぎに $n$ 回目の $K_{T}$ の設計 $($ Step B) にお いて,

$$
K_{T}^{(n)}=\underset{K_{T}}{\arg \min _{2}} J_{2}\left(K_{T}\right)=\underset{K_{T}}{\arg \min _{T}}\left\|T_{e w}\left(K_{R}^{(n)}, K_{T}\right)\right\|
$$

より，

$$
\left\|T_{e w}\left(K_{R}^{(n)}, K_{T}^{(n-1)}\right)\right\| \geq\left\|T_{e w}\left(K_{R}^{(n)}, K_{T}^{(n)}\right)\right\|
$$

であり,したがって

$$
\begin{aligned}
& \left\|\left[T_{e w}\left(K_{R}^{(n)}, K_{T}^{(n-1)}\right), T_{e n}\left(K_{R}^{(n)}\right)\right]\right\| \\
& \quad \geq\left\|\left[T_{e w}\left(K_{R}^{(n)}, K_{T}^{(n)}\right), T_{e n}\left(K_{R}^{(n)}\right)\right]\right\|
\end{aligned}
$$

が成り立つ。すなわち，

$$
J\left(K_{R}^{(n)}, K_{T}^{(n-1)}\right) \geq J\left(K_{R}^{(n)}, K_{T}^{(n)}\right)
$$

以上の (3) と (4)ょり

$$
J\left(K_{R}^{(n-1)}, K_{T}^{(n-1)}\right) \geq J\left(K_{R}^{(n)}, K_{T}^{(n)}\right)
$$

が成り立つ.また $(2)$ の定義より

$$
J\left(K_{R}^{(n)}, K_{T}^{(n)}\right) \geq J_{\mathrm{opt}}
$$

は明らかである。

\subsection{FSFH 近似手法による設計}

設計問題Step A 㧍よびStep B はむだ時間 $e^{-L s}$ 㧍よ びアップサンプラ $M ，$ ダウンサンプラ $\downarrow M$ を含むマル チレートサンプル值系の設計問題となるが, 参考文献 [6] でとられた手法, すなわち, 離散時間リフティング [4] お よびFSFH 近似手法 [11] の導入により単一レートの有限
次元離散時間系の設計問題へ帰着される。

まずマルチレートを単一レートに変換する。離散時間 リフティングを次式で定義する。

$$
\begin{aligned}
\mathbf{L}_{M} & :=(\downarrow M)\left[\begin{array}{llll}
1 & z & \ldots & z^{M-1}
\end{array}\right]^{T} \\
\mathbf{L}_{M}^{-1} & :=\left[\begin{array}{llll}
1 & z^{-1} & \cdots & z^{-M+1}
\end{array}\right](\uparrow M)
\end{aligned}
$$

このときつぎの補題が成り立つ $[5]$.

\section{【補題 1】}

$$
\begin{aligned}
(\downarrow M) K_{T}(z) \mathcal{S}_{h / M} & =\widetilde{K}_{T}(z) \widetilde{\mathcal{S}}_{h}, \\
\mathcal{H}_{h / M} K_{R}(z)(\uparrow M) & =\widetilde{\mathcal{H}}_{h} \widetilde{K}_{R}
\end{aligned}
$$

ただし，

$$
\begin{aligned}
\widetilde{K}_{T} & :=\left[\begin{array}{llll}
1 & 0 & \ldots & 0
\end{array}\right] \mathbf{L}_{M} K_{T}(z) \mathbf{L}_{M}^{-1}, \\
\widetilde{K}_{R} & :=\mathbf{L}_{M} K_{R}(z) \mathbf{L}_{M}^{-1}\left[\begin{array}{llll}
1 & 0 & \ldots & 0
\end{array}\right]^{T}, \\
\widetilde{\mathcal{S}}_{h} & :=\mathbf{L}_{M} \mathcal{S}_{h / M}, \\
\widetilde{\mathcal{H}}_{h} & :=\mathcal{H}_{h / M} \mathbf{L}_{M}^{-1}
\end{aligned}
$$

である.この補題より, Fig. 2 のマルチレート系は Fig. 3 の単一レート系へ変換される。

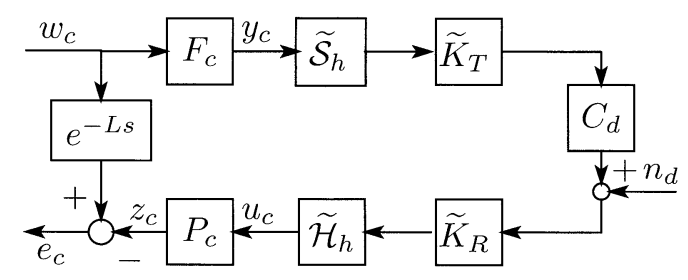

Fig. 3 Single-rate error system

つぎにファーストサンプルファーストホールド $(\mathrm{FSFH})$ 近似を導入し，むだ時間を含むサンプル值系を有限次元 の離散時間系へ变換する $[6]$.

【定理 1】むだ時間を $L=m h / M$ ( $m$ は自然数 $)$ と おく. 設計問題Step A 打よびStep B に扔けるマルチ レートサンプル値系にたいして, 有限次元離散時間シス テム $\left\{T_{R, N}: N=1,2, \ldots\right\}$ 抢よび $\left\{T_{T, N}: N=1,2, \ldots\right\}$ が 存在して次式が成り立つ。

$$
\begin{array}{r}
\lim _{N \rightarrow \infty}\left\|T_{R, N}\right\|_{\infty}=J_{1}\left(K_{R}\right), \\
\lim _{N \rightarrow \infty}\left\|T_{T, N}\right\|_{\infty}=J_{2}\left(K_{T}\right)
\end{array}
$$

（証明）FSFH 手法によりサンプル值系を離散化する。 ここでFSFH 手法とは, 周期 $h$ のサンプル值系の連続 時間入出力を, 周期 $h / N$ ( $N$ は自然数 $)$ で動作するサ ンプラとホールドによって離散化し，十分大きな $N$ に たいする離散時間信号で連続時間信号を近似する方法で ある (Fig. 4) 。さらに離散時間リフティング $\mathbf{L}_{N}$ を導入 ᄂ, $\widetilde{e}_{d N}:=\mathbf{L}_{N}\left(e_{d N}\right), \widetilde{w}_{d N}:=\mathbf{L}_{N}\left(w_{d N}\right)$ と変換する。こ のとき $\left\|e_{c}\right\|_{L^{2}} \approx \sqrt{\frac{h}{N}}\left\|\widetilde{e}_{d N}\right\|_{l^{2}},\left\|w_{c}\right\|_{L^{2}} \approx \sqrt{\frac{h}{N}}\left\|\widetilde{w}_{d N}\right\|_{l^{2}}$ が成り立ち,さらに $\left[\widetilde{w}_{d N}, n_{d}\right]^{T}$ から $\widetilde{e}_{d N}$ までのシステ 


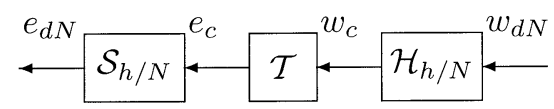

Fig. 4 FSFH discretization

ムを $T_{R, N}, \widetilde{w}_{d N}$ から $\widetilde{e}_{d N}$ までのシステムを $T_{T, N}$ とお くと, $T_{R, N}, T_{T, N}$ は有限次元離散時間系となる.また

$$
\begin{aligned}
\left\|T_{R, N}\right\|_{\infty}^{2} & :=\sup _{\widetilde{w}_{d N}, n_{d} \in l^{2}} \frac{\left\|\widetilde{w}_{d N}\right\|_{l^{2}}^{2}+\frac{N}{h}\left\|n_{d}\right\|_{l^{2}}^{2}}{\left\|\widetilde{e}_{d N}\right\|_{l^{2}}^{2}}, \\
\left\|T_{T, N}\right\|_{\infty} & :=\sup _{\widetilde{w}_{d N} \in l^{2}} \frac{\left\|\widetilde{e}_{d N}\right\|_{l^{2}}}{\left\|\widetilde{w}_{d N}\right\|_{l^{2}}}
\end{aligned}
$$

と定義すると，参考文献 [11]により（5）の収束が成り立 つ.

定理 1 における有限次元離散時間系の具体的な公式を 以下に示す.ただし, FSFHの分割数を $N=M l$ （l は自 然数）とおく.またプラント $G$ とフィルタ $K$ のフィー ドバック接続を $\mathcal{F}_{l}(G, K)$ と表わす.

$$
\begin{aligned}
& T_{R, N}:=\mathcal{F}_{l}\left(G_{R, N}, \widetilde{K}_{R}\right), \\
& T_{T, N}:=\mathcal{F}_{l}\left(G_{T, N}, \widetilde{K}_{T}\right), \\
& G_{R, N}:=\left[\begin{array}{cc}
{\left[z^{-m} F_{d N}, 0\right],} & -P_{d N} \mathbf{H} \\
\left.C_{d} \widetilde{K}_{T} \mathbf{S} F_{d N}, \sqrt{h / N}\right], & 0
\end{array}\right], \\
& G_{T, N}:=\left[\begin{array}{cc}
z^{-m} F_{d N}, & -P_{d N} \mathbf{H} \widetilde{K}_{R} C_{d} \\
\mathbf{S} F_{d N}, & 0
\end{array}\right], \\
& F_{d N}:=\mathbf{L}_{N} \mathcal{S}_{h / N} F \mathcal{H}_{h / N} \mathbf{L}_{N}^{-1}, \\
& P_{d N}:=\mathbf{L}_{N} \mathcal{S}_{h / N} P \mathcal{H}_{h / N} \mathbf{L}_{N}^{-1} \text {, } \\
& \mathbf{H}:=\operatorname{block} \operatorname{diag}\{\underbrace{H, \ldots, H}_{M}\} \in \Re^{M l \times M}, \\
& \mathbf{S}:=\text { block } \operatorname{diag}\{\underbrace{S, \ldots, S}_{M}\} \in \Re^{M \times M l},
\end{aligned}
$$

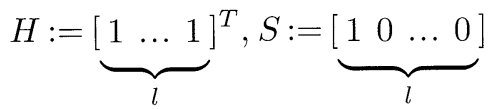

ここで $F_{d N}, P_{d N}$ はそれぞれ $N$ 入力 $N$ 出力の離散時間 LTI システムとなる $[1]$. 例えば $P(s)$ の状態空間実現を $(A, B, C, D)$ とおくと $P_{d N}$ の状態空間表現は次式で与え られる。

$$
\begin{aligned}
& P_{d N}=\left[\begin{array}{c|cccc}
\widetilde{A}^{N} & \widetilde{A}^{N-1} \widetilde{B} & \widetilde{A}^{N-2} \widetilde{B} & \cdots & \widetilde{B} \\
\hline C & D & 0 & \cdots & 0 \\
C \widetilde{A} & C \widetilde{B} & D & \cdots & 0 \\
\vdots & \vdots & \vdots & \ddots & \vdots \\
C \widetilde{A}^{N-1} \widetilde{B} & C \widetilde{A}^{N-2} \widetilde{B} & C \widetilde{A}^{N-3} \widetilde{B} & \cdots & D
\end{array}\right], \\
& \widetilde{A}:=e^{A h}, \quad \widetilde{B}:=\int_{0}^{h} e^{A \tau} B d \tau
\end{aligned}
$$

この結果より，もとのマルチレートサンプル值制御系 にたいする設計問題は離散時間系の設計問題に帰着され,
MATLAB などの数值解析ツールを用いて効率的にフィ ル夕を得ることができる。

\section{4. 設計例}

ここでは以下の設計パラメータを用いた設計例を示す.

$$
\begin{aligned}
F(s) & :=\frac{1}{10 s+1}, \quad P(s):=1, \\
C_{d}(z) & :=1+0.65 z^{-1}-0.52 z^{-2}-0.2975 z^{-3}
\end{aligned}
$$

なお，時間遅れは $L=2$ とし，FSFH 近似の分割数 $N$ を 4 とする。通信路のモデル $C_{d}(z)$ は参考文献 [2] から引 用した。この通信路 $C_{d}(z)$ のボード線図を Fig. 5 に示す. Fig. 5 からわかるように，この通信路は中域の周波数に おいてピークを持ち, 高域では減衰する特徵がある。こ のようなローパス特性は，ケーブル伝送などでしばしば 見られる特徴である $[7]$.

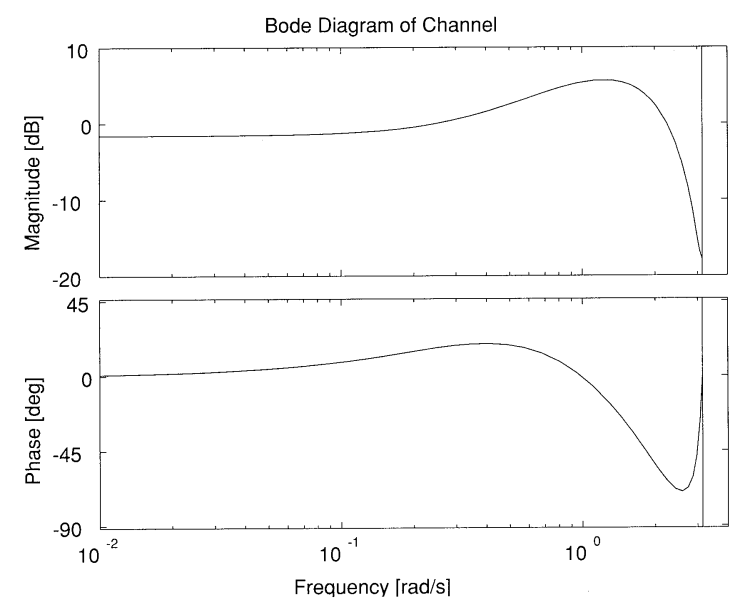

Fig. 5 Bode diagram of channel $C_{d}(z)$

\section{1 圧縮しない $(M=1)$ 場合}

Fig. 2 におけるサンプリング周期を $h=1$ とする。得 られた送受信フィルタのゲイン応答を Fig. 6 に示す。比 較のため離散時間設計，すなわち $F(s)=1$ のもとで系の 入出力をゼロ次ホールドによって離散化 [1] して設計し たときに得られた送受信フィル夕を同時に示す。サンプ ル值設計・離散時間設計ともに送信フィルタは信号を増 幅し, 受信フィルタは信号を減衰させる作用があること がわかる。

つぎに，得られたフィルタにたいする性能解析を示す. Fig. 7 に $T_{e w}$, Fig. 8 に $T_{e n}$ の周波数応答を示す ${ }^{1}$.

Fig. 7 より離散時間設計に比ベサンプル值設計はよい 復元性能を示していることがわかる。 また，Fig.8より， サンプル值設計では高周波の雑音にたいして良い減衰を 示しているが，低周波においては離散時間設計よりも悪 い結果となっている。

つぎに, 得られた送受信フィルタによるシミュレーショ

この周波数応答はサンプル值系としての応答である $[10]$. 以下の周波数応答も同様. 


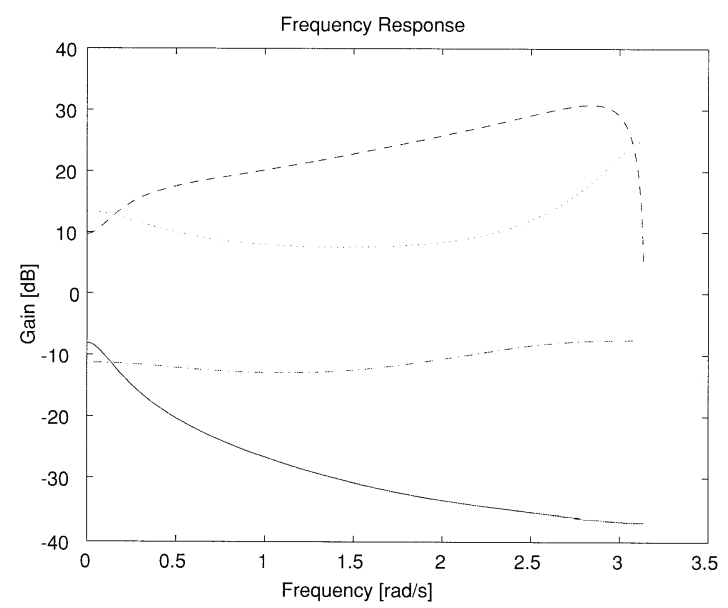

Fig. 6 Gain characteristic of filters: sampled-data design (transmitting filter (solid), receiving filter (dash) ), discrete-time design ( transmitting filter (dashdot), receiving filter (dot))

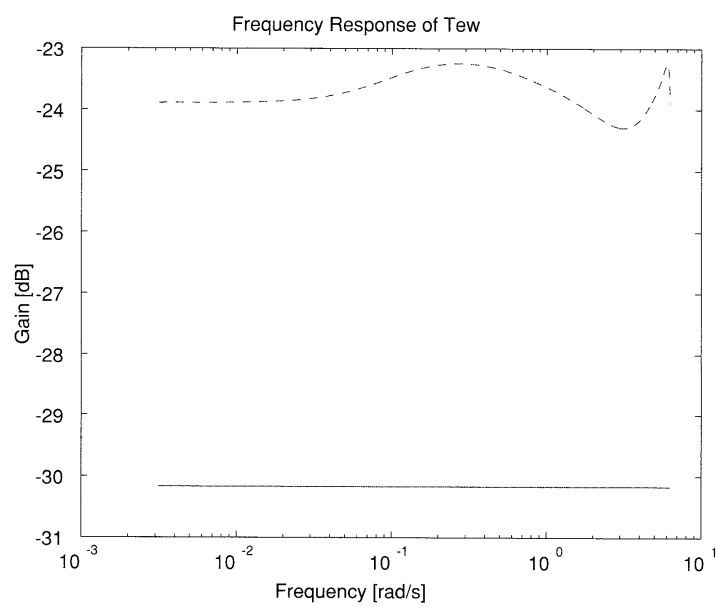

Fig. 7 Frequency response of $T_{e w}$ : sampled-data design (solid), discrete-time design(dash)

ンを示す. 送信信号として $w_{c}(t)=\sin (0.1 t)$, 雑音として $n_{d}(k)=\sin (3 k)$ を用いる。受信信号 $z_{c}(t)$ をFig. 9 （サ ンプル值設計）と Fig. 10 (離散時間設計) に示す。サン プル值設計された送受信フィルタがもとの送信信号を復 元できているのにたいし, 離散時間設計では雑音の影響 を大きく受けて，信号がうまく復元できていないことが わかる。

\section{2 圧縮がある場合}

つぎに $M=1,2,4,8$ として，圧縮した後送信を行う 系の設計例を示す. Fig. 2 におけるサンプリング周期は $h / M=1$ とする. このとき，送信される信号の情報量は それぞれ $1,1 / 2 ， 1 / 4 ， 1 / 8$ 倍に圧縮されることになる。 Fig. 11 に $T_{e w}$ の周波数応答, Fig. 12 に $T_{e n}$ の周波数応 答を示す. Fig. 11 より, 情報量を $1 / M$ 倍に圧縮したと き, $\left\|T_{e w}\right\|$ は圧縮しない場合に比べて約 $6 \times M \mathrm{~dB}$ 増加 することがわかる. とくに $M=2$ の場合は低周波領域

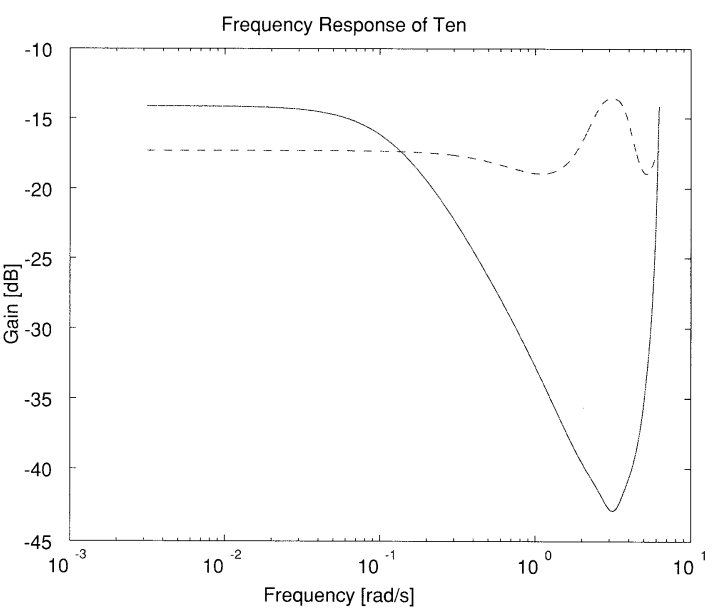

Fig. 8 Frequency response of $T_{e n}$ : sampled-data design (solid), discrete-time design (dash)

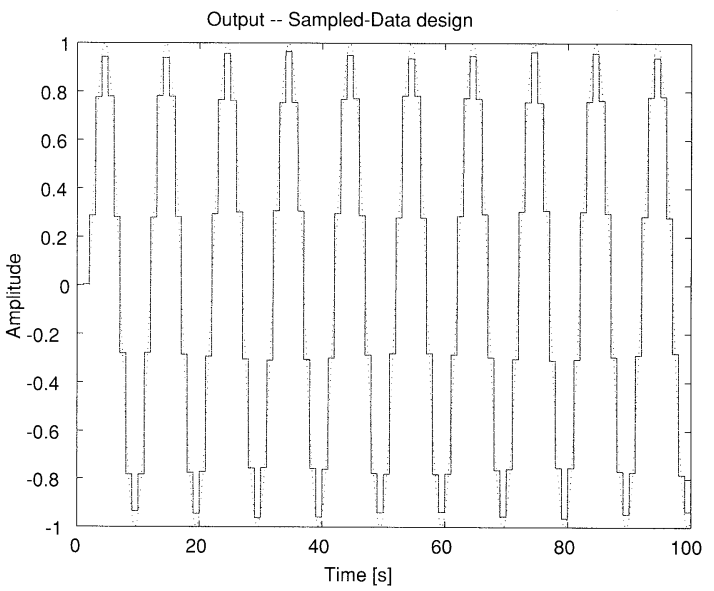

Fig. 9 Time response: sampled-data design(solid), original signal(dot)

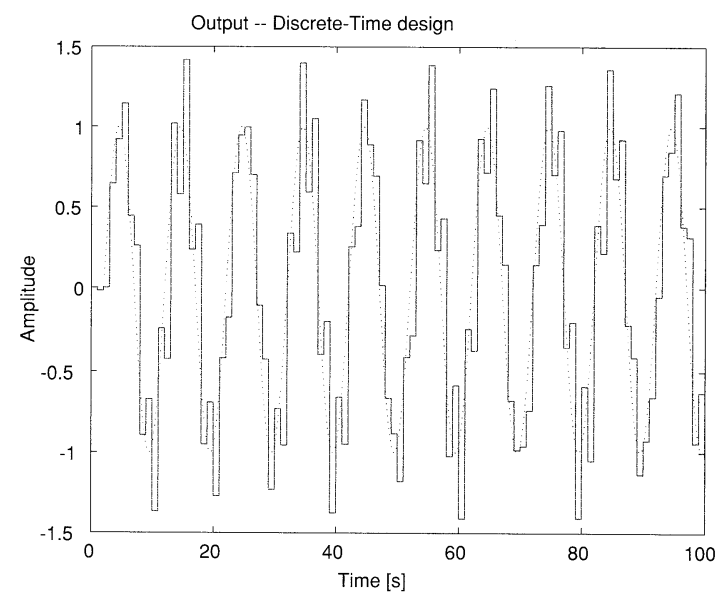

Fig. 10 Time response: discrete-time design(solid), original signal(dot)

において圧縮しないときと誤差が $0.5 \mathrm{~dB}$ 程度しか増加せ ず，それ以上の圧縮に比べて良い復元性能を示している。 また，Fig. 12 より，Fig. 11 とは逆に圧縮するにしたがっ 


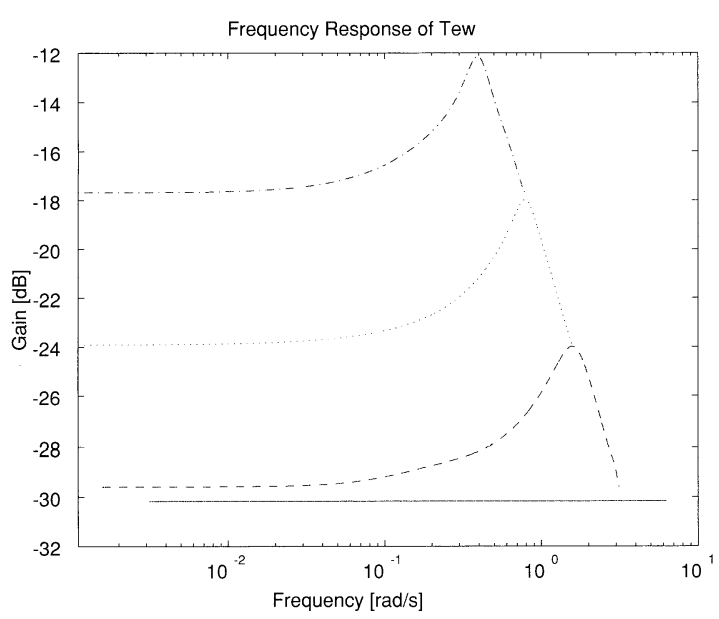

Fig. 11 Frequency response of $T_{e w}$ : compression ratio $M=1$ (solid), $M=2$ (dash), $M=4$ (dot), $M=8$ (dash-dot)

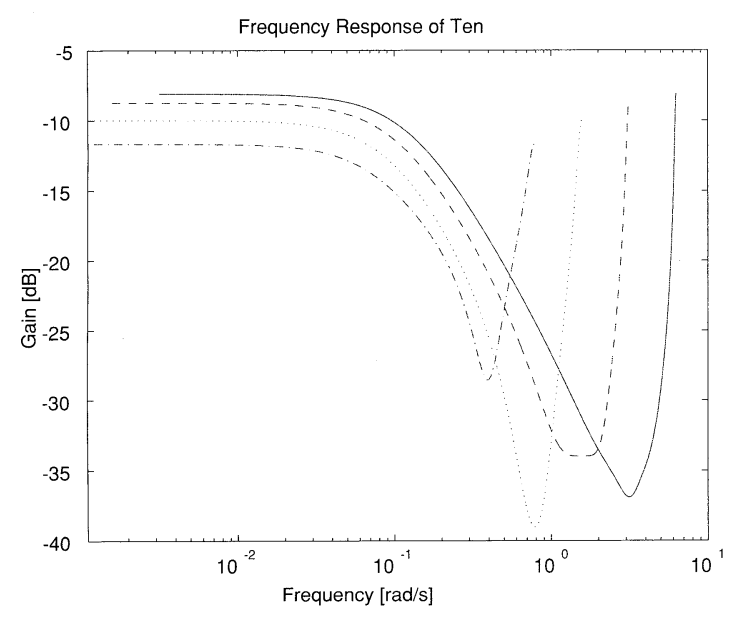

Fig. 12 Frequency response of $T_{\text {en }}$ : compression ratio $M=1$ (solid), $M=2$ (dash), $M=4$ (dot), $M=8$ (dash-dot)

て $\left\|T_{e n}\right\|$ は減少していることがわかる.

\section{5. おわりに}

本論文ではサンプル值 $H^{\infty}$ 制御を用いてディジタル通 信システムにおける送受信フィルタの設計手法を提案し た。アナログ特性を考慮した本設計手法は，特に音楽や 音声, 画像などのアナログ信号のディジタル伝送（PAM もしくはPCM 通信）に有効と考えられる。

\section{参考文献}

[1] T. Chen and B. A. Francis: Optimal Sampled-Data Control Systems, Springer (1995)

[2] A. T. Erdogan, B. Hassibi and T. Kailath: On linear $H^{\infty}$ equalization of communication channels; IEEE Trans. on Signal Processing, SP-48, pp. 3227-3232 (2000)

[3] H. Ito, T. Chuman, H. Ohmori and A. Sano: An approach to multirate control design with multiple objectives; Proc. of 13th IFAC World Congress, pp. 325-330 (1996)

[4] D. G. Meyer: A new class of shift-varying operators, their shift-invariant equivalents, and multi-rate digital systems; IEEE Trans. on Automatic Control, AC35, pp. 429-433 (1990)

[5] M. Nagahara and Y. Yamamoto: A new design for sample-rate converters; Proc. of 39th Conf. on Decision and Control, pp. 4296-4301 (2000)

[6] 永原, 山本：インターポレータのサンプル值 $H^{\infty}$ 設 計；システム制御情報学会論文誌, Vol. 14, No. 10, pp. 483-489, (2001)

[7] J. G. Proakis: Digital Communications, McGraw Hill (1989)

[8] M. F. Sagfors, H. T. Toivonen and B. Lennartson: $H_{\infty}$ control of multirate sampled-data systems; $A u$ tomatica, Vol. 34, pp. 415-428 (1998)

[9] Y. Yamamoto, H. Fujioka and P. P. Khargonekar: Signal reconstruction via sampled-data control with multirate filter banks; Proc. of 36th Conf. on Decision and Control, pp. 3395-3400 (1997)

[10] Y. Yamamoto and P. P. Khargonekar: Frequency response of sampled-data systems; IEEE Trans. on Automatic Control, AC-41, pp. 166-176 (1996)

[11] Y. Yamamoto, A. G. Madievski and B. D. O. Anderson: Approximation of frequency response for sampled-data control systems; Automatica, Vol. 35, pp. 729-734 (1999)

[12] 山本, 永原：サンプル值制御によるディジタル信号処 理；システム/制御/情報, Vol. 45, No. 4, pp. 162-167 (2001) 